\title{
Hypotensive and Antihypertensive Effects of Total Aqueous Extract of Justicia secunda Vahl M. (Acanthaceae) in Rabbits
}

\author{
ABO Kouakou Jean Claude ${ }^{1}$, KOUAKOU Kouakou Léandre ${ }^{2}$, YAPO Adou ${ }^{3}$ \\ ${ }^{1}$ Laboratory of Animal Physiology, UFR Biosciences, Felix Houphouet Boigny University, Abidjan, Ivory Coast \\ ${ }^{2}$ Laboratory of Animal Animal Physiology, Pharmacology and Pharmacopeia, UFR of Nature Sciences, Nangui Abrogoua University, \\ Abidjan, Ivory Coast \\ ${ }^{3}$ Laboratory of Pharmacodynamics Biochemical, UFR Biosciences, Felix Houphouet Boigny University, Abidjan, Ivory Coast
}

\begin{abstract}
The total aqueous extract of the leaves of Justicia secunda (Acanthaceae) from 1.25 to $75 \mathrm{mg} / \mathrm{kg}$ of body weight (BW) induced a dose-dependent hypotension in rabbits. The hypertension induced by adrenaline at $5.10^{-4} \mathrm{mg} / \mathrm{kg}$ of $B W$ is reduced by AJse administered at doses ranging from 10 to $30 \mathrm{mg} / \mathrm{kg} \mathrm{BW}$ in dose-dependent manner $(P<0.01)$. AJse, at $40 \mathrm{mg} / \mathrm{kg} \mathrm{BW,} \mathrm{cancels}$ completely the hypertension induced by adrenaline at $5.10^{-4} \mathrm{mg} / \mathrm{kg} \mathrm{BW}$ and provokes in consequence a hypotension. Additionally, AJse at $10-30 \mathrm{mg} / \mathrm{kg} \mathrm{BW}$ significantly reduces hypertension induced by the electrical stimulation of the sympathetic nerve fibers, and even cancel completely at $30 \mathrm{mg} / \mathrm{kg} \mathrm{BW}$ or superior doses. This aqueous extract of leaves of Justicia secunda is thus hypotensive and antihypertensive in rabbits. The antihypertensive effect induced by AJse extract in the presence of adrenaline, or upon his release following stimulation of the sympathetic nerve fibers, indicates that this extract would act by inhibiting $\beta$-adrenergic receptors. The total aqueous extract of Justicia secunda leaves therefore contains substances acting as beta-blockers. Hypotensive and antihypertensive properties of the total aqueous extract of Justicia secunda (Acanthaceae) justify the use of this plant in traditional medicine to treat high blood pressure.
\end{abstract}

Keywords: Justicia secunda, ß-adrenergic receptor, hypotension, hypertension, antihypertensive.

\section{Introduction}

Cardiovascular diseases are a major cause of death worldwide and hypertension is the most common of these diseases (Waeber et al, 1999). WHO considers cardiovascular disease in general and hypertension in particular as a public health problem in the world. In order to counter the rising cases of hypertension studies are undertaken to seek cost effective remedies against the disease. Several antihypertensive herbal recipe known and recognized for their therapeutic effects, are offered by traditional medicine for the treatment of this disease (Tra-Bi et al., 2008 ; WHO, 2012).

Justicia secunda M. Vahl (Acanthaceae) is a plant used in traditional medicine in Côte d'Ivoire (Tra-Bi et al., 2008) and the Caribbean (Etifier-Chalono, 2005) for its therapeutic properties in the treatment of hypertension. Some studies have shown that this plant is involved in reproduction (Lans, 2007). It has antimicrobial (Herrera et al., 2002; Rojas et al., 2006), abortive (Grenand et al., 1987) and anti-anemia (Chifundera, 2001 ; Moswa et al., 2008 ; Tossou et al., 2008 ; N'guessan et al., 2010) properties.

This study aims to verify the antihypertensive properties of aqueous leaf extract Justicia secunda which the decoction of leaves, in traditional medicine, is deemed effective in treating the high blood pressure.

\section{Materials and Methods}

\subsection{Biological material}

\subsubsection{Plant material}

Our study used fresh leaves of Justicia secunda (Acanthaceae) collected in Abidjan (Côte d'Ivoire). This plant was identified and authenticated by Mr. AKE-ASSI Laurent, Professor Emeritus of Botany at the University Felix Houphouet Boigny (Côte d'Ivoire). A specimen is deposited under the number 21160 in the herbarium of the National Centre of Floristic (CNF) of this University.

\subsubsection{Preparation of total aqueous extract of Justicia} secunda (AJse)

Fifty grams $(50 \mathrm{~g})$ of fresh leaves of Justicia secunda (Acanthaceae) are dropped in one liter $(1 \mathrm{~L})$ of distilled water. The mixture is boiled for ten minutes $(10 \mathrm{~min})$. The decoction obtained is filtered three times on cotton wool and Whatman filter paper. The filtrate was dried in an oven at 50 ${ }^{\circ} \mathrm{C}$ and then lyophilized. The powder obtained is the total aqueous extract of Justicia secunda (AJse).

\subsubsection{Animals}

Rabbits of the specie Oryctolagus cuniculus (Leporidae), were used for these experiments. Specimens used weigh between 2 and $2.5 \mathrm{~kg}$. These animals were brought from different farms located in the suburbs of Abidjan (Côte d'Ivoire). Before the experiments, they were acclimated to laboratory conditions in the Department of Biosciences of the University Felix Houphouet Boigny for one week to regulate and harmonize their physiological states. Thus, they were kept at constant temperature $\left(24 \pm 2{ }^{\circ} \mathrm{C}\right)$ with $50-55 \%$ 


\section{International Journal of Science and Research (IJSR) \\ ISSN (Online): 2319-7064 \\ Index Copernicus Value (2013): 6.14 | Impact Factor (2015): 6.391}

of humidity and a photoperiod of 12 hours of daylight and 12 hours of darkness. They are fed ad libitum with pellet (Ivograin, Abidjan, Côte d'Ivoire) and water. They were carefully screened and confirmed to be healthy during the period of acclimatization and experimentation. All the procedures were conducted in accordance with the guidelines for Care and Use of Laboratory Animals published by the National Institutes of Health.

\subsection{Recording arterial blood pressure of Rabbit}

The recording of arterial blood pressure of rabbits was performed with a Ludwig mercury manometer. Before intubation of the carotid artery of the animal, a pressure gauge is made in the manometer according to the method described by Abo et al. (2000). In accordance with the National Government rules of Côte-d'Ivoire, rabbit was anesthetized through intraperitoneal injection of ethyl carbamate dosed at $40 \%, 1 \mathrm{~g} / \mathrm{kg} \mathrm{BW}$. His carotid artery was exposed and intubated and connected to the heart through a polyvinyl tube and the manometer, this allowed us to obtain directly the intracarotid pressure which was recorded on a recording paper. Our method of recording arterial blood pressure by the bloody method is similar to that described by Abo et al. (2000). The saphenous vein was intubated with a catheter connected to a syringe for the administration of pharmacodynamic substances and the extract. A sympathetic nerve is identified at the neck of the animal. It was stimulated with exciting electrodes connected to an electrical stimulator (JEULIN, Réf : 554 035).

\subsection{Substance pharmacodynamic}

The pharmacological substance used in this study is adrenaline (L-adrenaline) from FLUKA (Germany).

\subsection{Statistical analysis of results}

The computer program GraphPad InStat (San Diego CA, USA) was used for statistical analysis of results. Values are given as mean followed by the standard error of the mean. The difference between two values/was determined by Student-Newman-Keuls comparison test. It was considered significant for $\mathrm{p}<0.05$. The computer program GraphPad Prism 5 (San Diego CA) was used for plotting graphs. Sigmoid curve was drawn after transformation of values of $\mathrm{x}$-axis as decimal logarithm and as a percentage for the $\mathrm{y}$ axis.

\section{Results}

\subsection{Dose-response effect of total aqueous extract of Justicia secunda (AJse) on normal blood pressure}

In this study, increasing doses of $\mathrm{A} J \mathrm{se}$ were injected to rabbits, in time intervals of 15 minutes after the effect of each dose. $\mathrm{A} J \mathrm{se}$ administered in increasing doses from 1.25 to $75 \mathrm{mg} / \mathrm{kg} \mathrm{BW}$ induced a drop in blood pressure. This hypotension was dose-dependent. AJse doses below 1.25 $\mathrm{mg} / \mathrm{kg} \mathrm{BW}$ had no effect on blood pressure. The figure 1-a shows a typical recordings of the effects of $\mathrm{A} J$ se on blood pressure of rabbit. In this first series of experiments to study, the average of normal blood pressure of rabbits used was 95 $\pm 6 \mathrm{~mm} \mathrm{Hg}(\mathrm{n}=4)$. The injection of AJse gave three types of results according to the doses of the extract.

- The extract of AJse, between 1.25 and $40 \mathrm{mg} / \mathrm{kg} \mathrm{BW}$, induced hypotension ranging from 5 to $28 \mathrm{~mm} \mathrm{Hg}$, resulting a drop in blood pressure ranging from $5.21 \%$ to $29.17 \%$ compared to the reference blood pressure of rabbit used. At these doses, the AJse effects are completely reversible.

- However, doses of 50-60 mg/kg BW induced a hypotension partially reversible. The decrease in the blood pressure varied from 33 to $36 \mathrm{~mm} \mathrm{Hg}$. The reduction of the blood pressure ranged from $34.35 \%$ to $37.5 \%$ compared to the reference blood pressure of rabbits used.

- For the doses of AJse superior or equal to $75 \mathrm{mg} / \mathrm{kg} \mathrm{BW}$, the induced hypotension, greater or equal to $38 \mathrm{~mm} \mathrm{Hg}$, was irreversible and became lethal from $100 \mathrm{mg} / \mathrm{kg} \mathrm{BW}$.

The curve in Figure 1-b shows the percentages of the decrease of arterial blood pressures recorded compared to the reference used rabbits in the presence of increasing doses of $\mathrm{AJ}$ se for 4 experiments. This sigmoidal curve allowed us to determine the value of the $50 \%$ effective dose $\left(E_{50}\right)$ of $\mathrm{A} J_{s e}$ which is $15.17 \mathrm{mg} / \mathrm{kg}$ body weight.

\subsection{Effects of AJse on induced-hypertension in rabbit}

\subsubsection{Effects of AJse on the hypertension induced by} adrenaline

The purpose of this study was to measure the effects of $\mathrm{A} J s \mathrm{e}$ on the hypertension induced by the administration of adrenaline. Thus, in a first series of experiments, the injection of different doses of $\mathrm{A} J s \mathrm{e}$ was preceded by the injection of a single dose of adrenaline. The figure 2-a shows a typical recordings of the results of this series of experiments. Adrenaline, at $5.10^{-4} \mathrm{mg} / \mathrm{kg} \mathrm{BW}$, increased blood pressure of $52.75 \pm 4.25 \mathrm{~mm} \mathrm{Hg}$ (Figure 2-a-A). When the injection of the same dose of adrenaline $\left(5.10^{-4}\right.$ $\mathrm{mg} / \mathrm{kg} \mathrm{BW}$ ) was followed, after $10 \mathrm{~s}$, by the injection of $\mathrm{A} J \mathrm{se}$ in the concentration range of 10 to $30 \mathrm{mg} / \mathrm{kg} \mathrm{BW}$, adrenaline induced hypertension is reduced. This decrease in the blood pressure is dose-dependent and varied from 4.74 $\%$ to $51.18 \%$. When the injection of adrenaline at $5.10^{-4}$ $\mathrm{mg} / \mathrm{kg} \mathrm{BW}$ was followed by $\mathrm{A} J \mathrm{se}$ at $40 \mathrm{mg} / \mathrm{kg} \mathrm{BW}$, it appeared a transient hypertension of $8.25 \pm 2.18 \mathrm{~mm} \mathrm{Hg}$, followed by a hypotension of $6.5 \pm 2.04 \mathrm{~mm} \mathrm{Hg}$. Thus, AJse at $40 \mathrm{mg} / \mathrm{kg} \mathrm{BW}$, completely reversed the hypertension induced by adrenaline at $5.10^{-4} \mathrm{mg} / \mathrm{kg} \mathrm{BW}$ and provoked hypotension. The columns in Figure 2-b shows the effects of A $J$ se on hypertension induced by adrenaline for 4 series of experiments.

In the second series of experiments, adrenaline at $5.10^{-4}$ $\mathrm{mg} / \mathrm{kg}$ body weight was associated with increasing doses of AJse and administered to rabbits. The figure 3-a shows a typical recordings of the results of this second series of experiments. Injected alone to rabbits, adrenaline at $5.10^{-4}$ $\mathrm{mg} / \mathrm{kg} \mathrm{BW}$ induced hypertension of $50.75 \pm 3.25 \mathrm{~mm} \mathrm{Hg}$ $(n=4)$. When the adrenaline was associated with different doses of $\mathrm{A} J s \mathrm{~s}$, hypertension was reduced proportionally to the dose of the extract. Indeed, with a dose of adrenaline of $5.10^{-4} \mathrm{mg} / \mathrm{kg} \mathrm{BW}$ associated with $\mathrm{A} J$ se ranging from 5 to 30 $\mathrm{mg} / \mathrm{kg} \mathrm{BW}$, the increased of the blood pressure, which 


\section{International Journal of Science and Research (IJSR) \\ ISSN (Online): 2319-7064 \\ Index Copernicus Value (2013): 6.14 | Impact Factor (2015): 6.391}

initially were $50.75 \pm 3,25 \mathrm{~mm} \mathrm{Hg}$ in the presence of adrenaline alone decreased. For these $\mathrm{A} J$ se doses, the values of the hypertension induced by adrenaline varied between $38.75 \pm 2.95 \mathrm{~mm} \mathrm{Hg}$ and $4 \mathrm{~mm} \mathrm{Hg} \pm 1.91$, which corresponded to a reduction in blood pressure ranging from $23.65 \%$ to $92.12 \%$. At $40 \mathrm{mg} / \mathrm{kg} \mathrm{BW} \mathrm{AJse} \mathrm{totally} \mathrm{cancelled}$ the hypertension induced by the adrenaline at $5.10^{-4} \mathrm{mg} / \mathrm{kg}$ BW because the two compounds associated at these doses didn't provoke hypertension. It was rather observed a hypotension of $4.5 \pm 2.65 \mathrm{~mm} \mathrm{Hg}$. The columns in Figure 3$\mathrm{b}$ shows the hypertension induced by adrenaline in the presence of AJse for 4 series of experiments.

\subsubsection{Effects of AJse on hypertension induced by sympathetic nerve stimulation in rabbit}

In this series of experiments, we determined the effects of $\mathrm{A} J$ se on the hypertension induced by the stimulation of the peripheral nervous system. Thus, stimulation of the sympathetic nerve of the rabbit was immediately followed by the injection of $A J s e$ at different doses. Figure 4-a show a typical recording of the results of this series of experiments. Electrical stimulation of the sympathetic nerve of rabbits induced an increased blood pressure of $15 \pm 2.82 \mathrm{~mm} \mathrm{Hg}$ throughout the duration of the stimulation (45 s) (Figure 4-aA). When stimulation of the sympathetic nerve is followed after $3 \mathrm{~s}$, by the administration of $\mathrm{A} J \mathrm{se}$ at $10 \mathrm{mg} / \mathrm{kg} \mathrm{BW}$, the increased of blood pressure obtained was $11.25 \pm 3.82 \mathrm{~mm}$ $\mathrm{Hg}$; resulting $25 \%$ of drop in blood pressure, while stimulation was maintained for $1 \mathrm{~min}$. A $J$ se administered at a dose of $20 \mathrm{mg} / \mathrm{kg} \mathrm{BW}$, after sympathetic nerve stimulation induced a transient decrease in the blood pressure of $6.76 \pm$ $3.86 \mathrm{~mm} \mathrm{Hg}$, followed by a return to a normal high blood pressure despite the continued stimulation of the nerve (for 1 min). The hypertension induced by stimulation of the sympathetic nerve disappeared immediately after the administration of $\mathrm{A} J \mathrm{se}$ at $30 \mathrm{mg} / \mathrm{kg} \mathrm{BW}$ and a hypotension of $4.5 \pm 2.66 \mathrm{~mm} \mathrm{Hg}$ appeared.

Thus, AJse significantly reduced and even canceled hypertension induced by stimulation of the sympathetic nerve. The results obtained from the four series of experiments had enable us to plot the columns in Figure 4-b showing the effects of $\mathrm{A} J \mathrm{se}$ on hypertension induced by stimulation of the sympathetic nerve.

\section{Discussion}

The total aqueous extract of Justicia secunda (AJse) at doses ranging from 1.25 to $75 \mathrm{mg} / \mathrm{kg}$ BW induced in rabbit dosedependent hypertension. This extract reduced and even canceled hypertension induced by adrenaline at $5.10^{-4} \mathrm{mg} / \mathrm{kg}$ $\mathrm{BW}$ or electrical stimulation of the sympathetic nerve fibers of the rabbit. AJse is therefore a hypotensive and antihypertensive substance. The hypotensive properties of Justicia secunda were also noted by Manda et al. (2011).

Stimulation of orthosympathetic fibers causes the release of adrenaline from the nerve endings of these fibers. To act on the cardiovascular system, the substance binds to $\beta$ adrenergic receptors (Castaigne, 1988). According to Lands et al. (1967 and 1976), there are two sub-types of receptor $\beta$ : $\beta 1$ and $\beta 2$ adrenergic receptors. In the myocardial cells, $\beta 1$ receptors are predominant. The binding of a $\beta 1$ adrenergic agonist to its specific receptor leads to an increase in cardiac output, increased cardiac contractility leading to an increase in blood ejection volume (Witchitz, 1994, Brown, 1995; Westfall and Westfall, 2006). Classically, vascular $\beta$ adrenergic receptors are of type $\beta 2$ and their stimulation causes vasoconstriction (Berdeaux and Edward, 1997; Guimaraes and Moura, 2001). Cardioactivateurs and vasoconstrictor effects of adrenaline cause rise in blood pressure (Castaigne, 1988 ; Berdeaux and Edward, 1997).

The inhibition of hypertension induced by adrenaline administered or released after stimulation of sympathetic nerve fibers of rabbit, by $\mathrm{A} J$ se indicates that this extract would act by inhibiting the effects of activation of $\beta$ adrenergic receptors. The total aqueous extract of Justicia secunda therefore contains substances acting as betablockers. Indeed, beta blockers or beta-adrenergic or antiadrenergic beta are competitive inhibitors of the effects of catecholamines on $\beta$-adrenergic receptors (Castaigne, 1988 ; Witchitz, 1994, Brown, 1995 ; Westfall and Westfall, 2006). Beta-blockers inhibit specifically and competitively peripheral and also central beta-adrenergic receptors if they pass the blood-brain barrier. They have common effects essentially on cardiovascular system. They act primarily by reducing the activity of catecholamines on the heart and blood vessels and also decrease blood pressure (Bradley et al., 2006 ; Heusser et al., 2007 ; Wiysonge et al., 2007).

\section{Conclusion}

This study shows that the total Justicia secunda aqueous extract contains hypotensive and antihypertensive substances. These properties of this extract of Justicia secunda justify the use of this plant in traditional medicine to treat high blood pressure.

\section{References}

[1] Abo K. J. C., Ehile E. E., Guede-Guina F., Traore F. 2000. Effets cholinergiques d'un extrait aqueux de Mareya micranttha (Euphorbiaceae) sur la pression artérielle et l'activité cardiaque. Afr bioméd. 5 (3) : 11 20.

[2] Berdeaux A., Edouard A. 1997. Pharmacologie des récepteurs adrénergiques et dopaminergiques. Implications thérapeutiques actuelles. Services de Pharmacologie et d'Anesthésie-Réanimation, Centre Hospitalier de Bicêtre, 94275 Le Kremlin Bicêtre Cedex, France, MAPAR. pp 397-413.

[3] Bradley H. A., Wiysonge C. S., Volmink J. A., Mayosi B. M., Opie L. H. 2006. How strong is the evidence for use of beta-blockers as first-line therapy for hypertension ? Systematic review and meta-analysis. J Hypertens. 24(11) : 2131-2141.

[4] Brown O. M. 1995. Adrenergic Drugs and Adrenergic Antagonists. In : Essentials of pharmacology. Edited par Smith C. M. Reynard A. M. W-B Saunders Company, Philadelphia, USA. pp 75-91.

[5] Castaigne A. 1988. Bêta-stimulants et Bêta-bloquants. Pour la pratique. Rev Prat ; 38 : 569-572.

[6] Chifundera K. 2001. Contribution to the inventory of medicinal plants from the Bushi area, South Kivu 


\section{International Journal of Science and Research (IJSR) \\ ISSN (Online): 2319-7064}

Index Copernicus Value (2013): 6.14 | Impact Factor (2015): 6.391

Province, Democratic Republic of Congo. Fitoterapia. 72(4) : 351-368.

[7] Etifier-Chalono E. 2005. Quelques plantes médicinales utilisées par les Amérindiens. Lobelia. $4: 4$ p.

[8] Grenand P., Moretti C., Jacquemin H. 1987. Pharmacopées traditionnelles en Guyane. ORSTOM, France. pp 89-90.

[9] Guimaraes S., Moura D. 2001. Vascular adrenoceptors ; an update. Pharmacol Rev. $53: 319-356$.

[10] Herrera M. H., Rosas R. A., Crescente O. V., 2002. Biological activity of "Sanguinaria" (Justicia secunda) extracts. Pharmaceutical Biology (Formerly International Journal of Pharmacognosy). 40(3) : 206212.

[11] Heusser K., Engeli S., Tank J. 2007. Sympathetic vasomotor tone determines blood pressure response to long-term sibutramine treatment. Journal of Clinical Endocrinology and Metabolism. 92(4) : 1560-1563.

[12] N'Guessan K., Kouassi K. H., Ouattara K. 2010. Plants used to treat anaemia, in traditional medicine, by Abbey and Krobou populations, in the South of Côte d'Ivoire. J Appl Sci Res. 6 : 1291-1297.

[13] Lands A. M., Arnold A., M. C. Auliff J. P., Luduena F. P., Brown T. G. 1967. Differentiation of receptor systems activated by sympathomimetic amines. Nature. 214 : 597-598.

[14] Lands A. M., Luduena F. P., Buzzo H. J. 1976. Differentiation of receptor responsive to isoproterenol. Life Sci. 6 : 2241-2249.

[15] Lans C., 2007. Ethnomedicines used in Trinidad and Tobago for reproductive problems. J Ethnobiol Ethnomed. $15: 3-13$.

[16] P. Manda, D. P. Abrogoua, C. Bahi, D. S. Dano, G. Gnahoui, B. J. Kablan 2011. Evaluation of the antihypertensive activity of total aqueous extract of Justicia secunda Valh (Acanthaceae). African Journal of Pharmacy and Pharmacology. 5(16) : 1838-1845.

[17] Moswa J. L., Kapanda N., Mungende D. M., Okitolonda W., Mayangi M., Mihigo S.' Mbale K. 2008. Plants as an important source of iron for the treatment of anaemia : case of Justicia secunda. $11^{\text {th }}$ NAPRECA Symposium Book of Proceedings, Antananarivo, Madagascar. pp 132-135.

[18] Rojas J. J., Ochoa V. J., Ocampo S. A., Muñoz J. F. 2006. Screening for antimicrobial activity of ten medicinal plants used in Colombian folkloric medicine : a possible alternative in the treatment of nonnosocomial infections. BMC Compl Alter Med. 17 : 612.

[19] Tossou R., Gbenou J. D., Dansou P., Fossou M., Moudachirou M. 2008. Etude des propriétés antianémiques de Justicia secunda Vahl (Acanthaceae) chez des rats de souche Wistar. Rev CAMES, Série A. 6 :26-29.

[20] Tra-Bi F. H., Irié G. M., N'Gaman K. C. C., Mohou C. H. B. 2008. Etudes de quelques plantes thérapeutiques utilisées dans le traitement de l'hypertension artérielle et du diabète : deux maladies émergentes en Côte d'Ivoire. Sci Nat. 5(1) : 39-48.

[21] Westfall T. C., Westfall D. P. 2006. Adrenergic agonists and antagonists. In : L. L. Brunton, J. S. Lazo, and K. L. Parker (eds) Goodman and Gilman's, The
Pharmacological Basis of Therapeutics. McGraw-Hill, New York, USA, $11^{\text {th }}$ edition. pp 237-295.

[22] WHO 2012. The global importance of plant-derived drugs. www.who.org.

[23] Witchitz S. 1994. Bêta-bloqueurs. Editions Techniques. Encycl Méd Chir Paris, France. CardiologieAngéiologie. 11-903-A-10, 7 p.

[24] Wiysonge C. S., Bradley H., Mayosi B. M., Maroney R., Mbewu A., Opie L. H., Volmink J. 2007. Betablockers for hypertension. Cochrane Database Syst Rev. 24(1) : CD002003. 


\section{International Journal of Science and Research (IJSR) \\ ISSN (Online): 2319-7064}

Index Copernicus Value (2013): 6.14 | Impact Factor (2015): 6.391

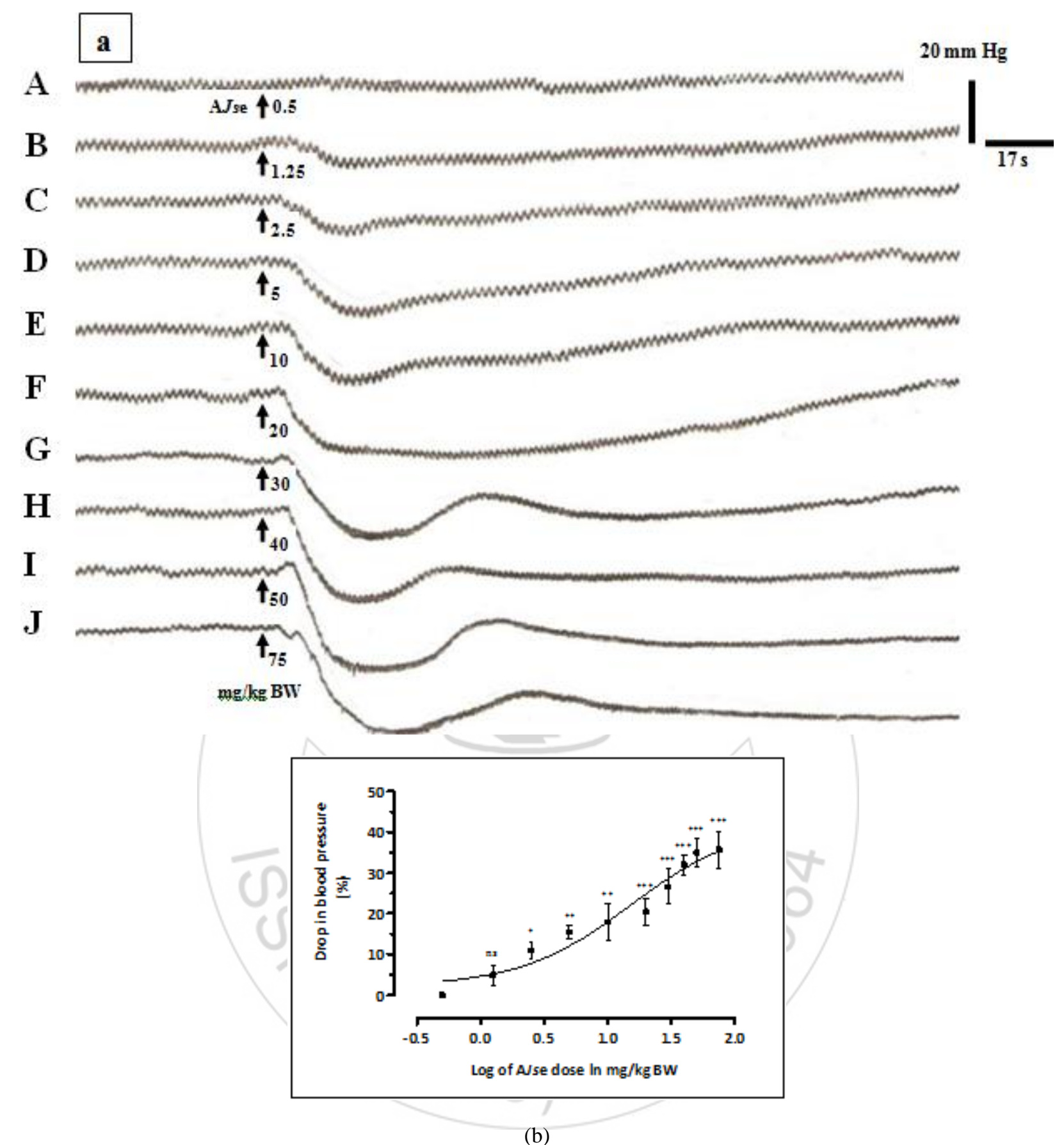

Figure 1: dose-response effects of an aqueous extract of Justicia secunda total (AJse) on arterial blood pressure of rabbit a - Recording result

A to J - Effects of AJse (after the arrow) at 0.5 (A), $1.25(\mathrm{~B}), 2.5(\mathrm{C}), 5(\mathrm{D}), 10(\mathrm{E}), 20$ (F), 30 (G), 40 (H), 50 (I) and 75 (J) $\mathrm{mg} / \mathrm{kg}$ body weight (BW)

$b$ - Drop in blood pressure according to the dose of AJse Administered

$\mathbf{n}=4, \mathrm{~ns} \mathrm{P}>0.05, * \mathrm{P}<0.05, * * \mathrm{P}<0.01, * * * \mathrm{P}<0.001$.

AJse causes a dose-dependent hypotension in rabbit.

The curve showing the effect of AJse on blood pressure is a sigmoid.

Volume 5 Issue 5, May 2016

www.ijsr.net 
A

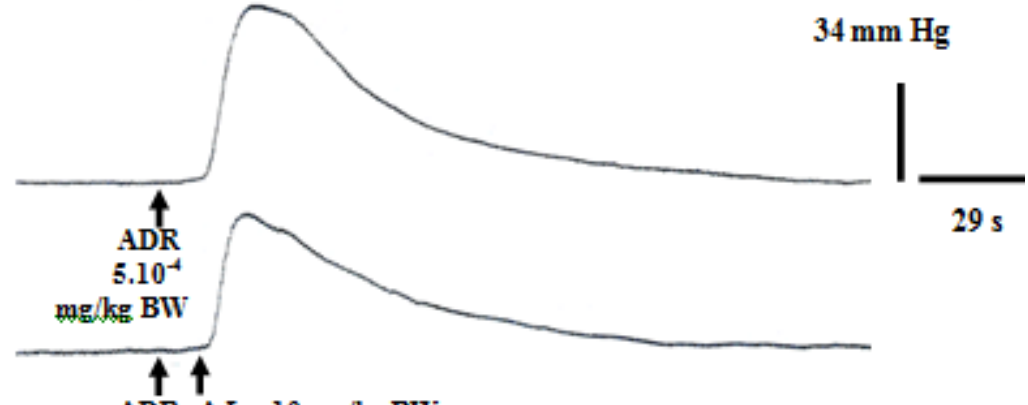

$\mathrm{C}$

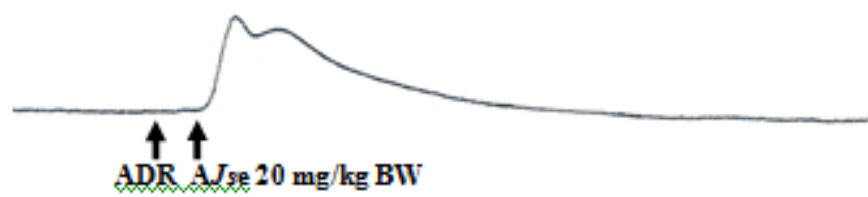

D

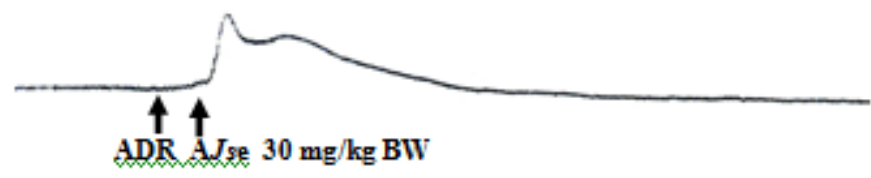

$\mathbf{E}$
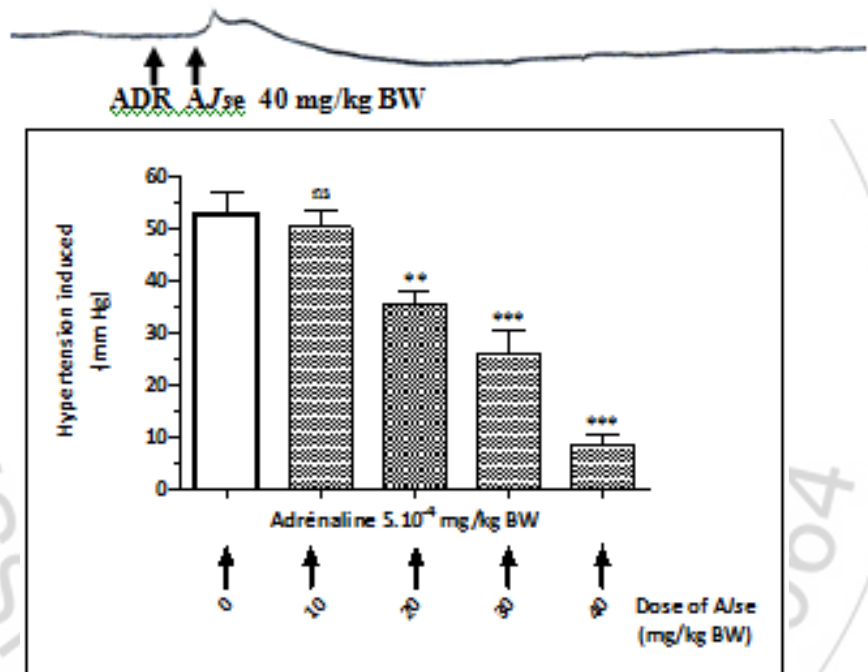

(b)

Figure 2: Effects of a total aqueous extract of Justicia secunda (AJse) on hypertension Induced by adrenaline administration in rabbit

a-Recording result

A - Effects of adrenaline (ADR) at $5.10^{-4} \mathrm{mg} / \mathrm{kg}$ body weight (BW)

B to $\mathbf{E}$ - Effects of ADR at $5.10^{-4} \mathrm{mg} / \mathrm{kg}$ body weight, followed by injection of AJse at $10(\mathrm{~B})$, 20 (C), 30 (D) and 40 (E) $\mathrm{mg} / \mathrm{kg} \mathrm{BW}$

$\mathrm{b}$ - Decrease in hypertension induced by adrenaline by $\mathrm{AJ} s \mathrm{se}$ $\mathbf{n}=4$, ns $\mathrm{P}>0.05, * * \mathrm{P}<0.01, * * * \mathrm{P}<0.001$.

Hypertension induced by administration of adrenaline was significantly reduced in the presence of AJse. 


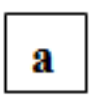

A

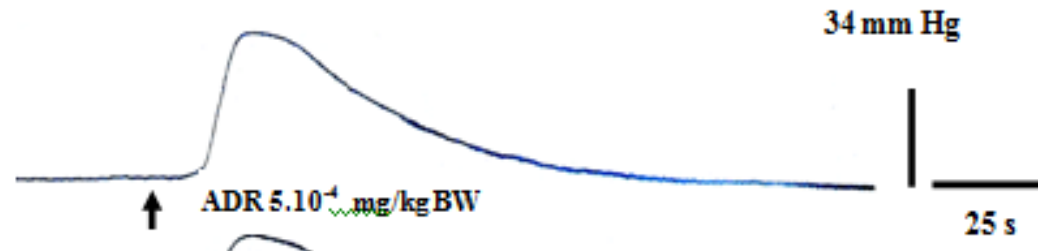

B

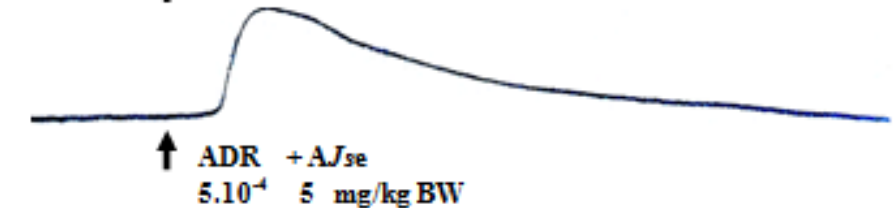

$25 \mathrm{~s}$

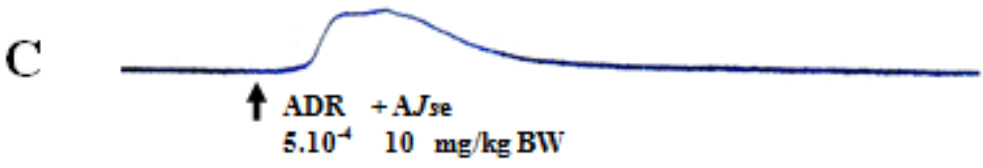

D

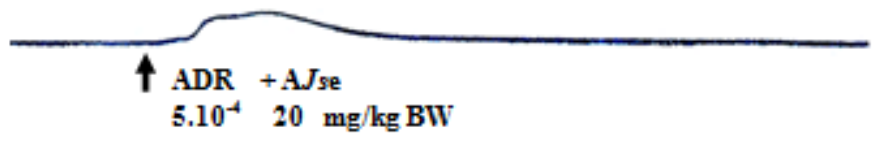

$\mathbf{E}$

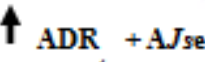

$5.10^{-4} \quad 30 \mathrm{mg} / \mathrm{kg} \mathrm{BW}$

$\mathbf{F}$
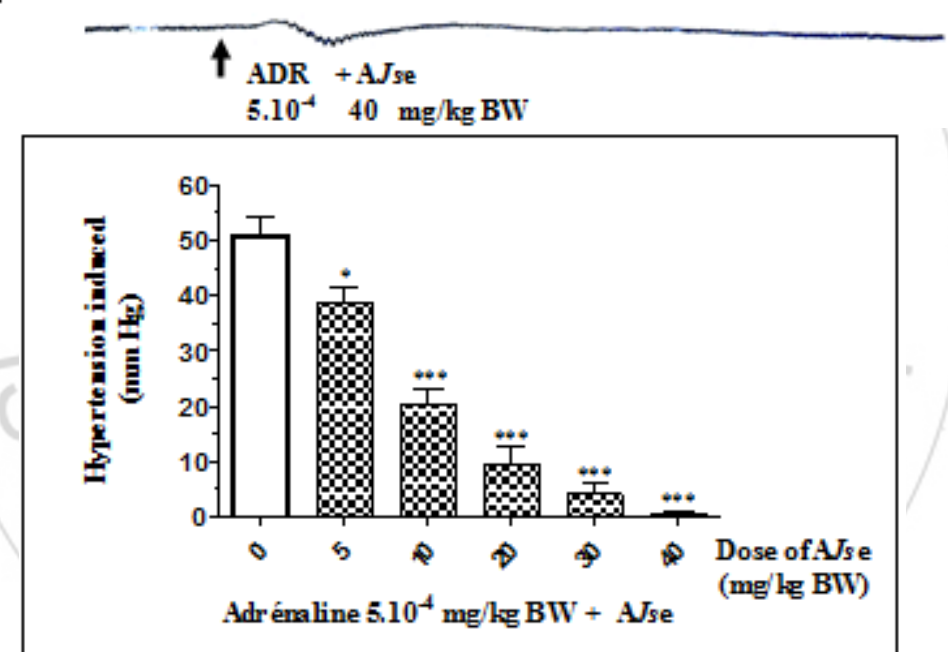

(b)

Figure 3: Cumulative effects of total aqueous extract of Justicia secunda (AJse) and adrenaline on the arterial blood pressure of rabbit a - Recording result

A - Effects of ADR at $5.10^{-4} \mathrm{mg} / \mathrm{kg}$ body weight $(\mathrm{BW})$

B to F - Effects of ADR at $5.10^{-4} \mathrm{mg} / \mathrm{kg} \mathrm{BW}+\mathrm{A} J \mathrm{se}$ at $5(\mathrm{~B}), 10(\mathrm{C}), 20(\mathrm{D}), 30(\mathrm{E})$ and $40(\mathrm{~F}) \mathrm{mg} / \mathrm{kg} \mathrm{BW}$

b - Hypertension induced by Adrenaline in the presence of Ajse $(\mathbf{n}=4, * \mathrm{P}<0.05, * * * \mathrm{P}<0.001)$

AJse significantly reduced and even canceled the hypertension induced by the administration of Adrenaline to the rabbit. 


\section{$\mathbf{a}$}

$25 \mathrm{~mm} \mathrm{Hg}$

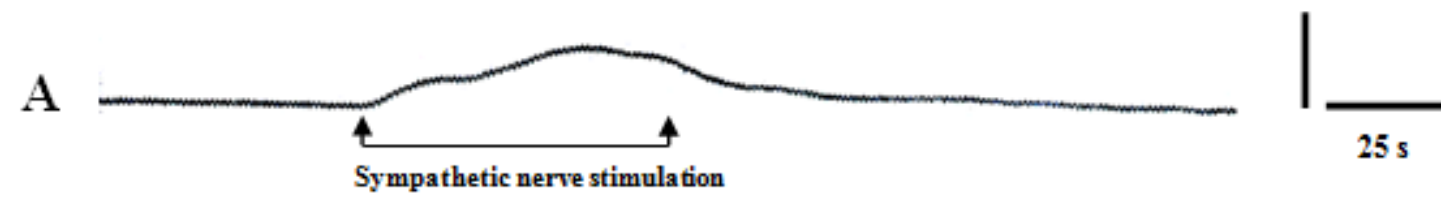

Sympathetic nerve stimulation

A $J_{\text {se }} 20 \mathrm{mg} / \mathrm{kg}$ BW

D

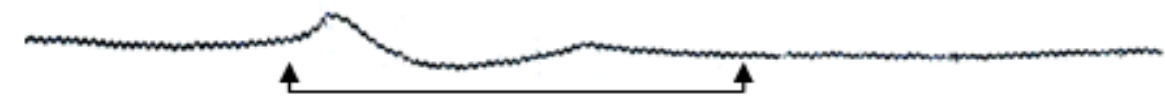

Sympathetic nerve stimulation

$\uparrow$

A $J_{\text {se }} 30 \mathrm{mg} / \mathrm{kg} \mathrm{BWV}$

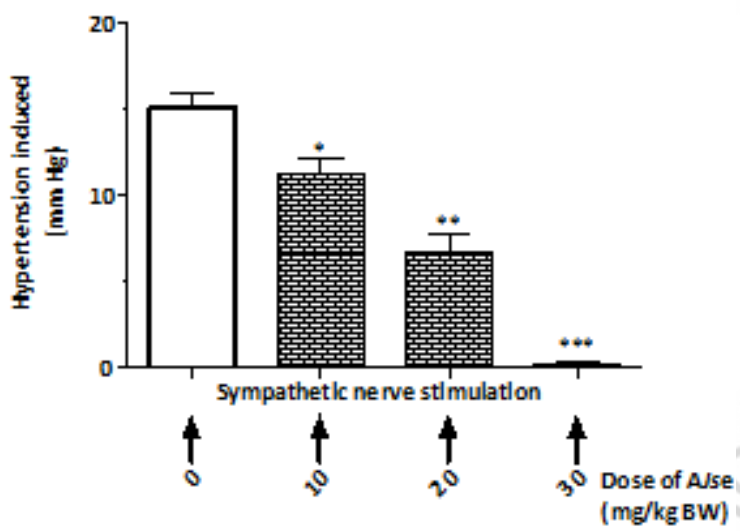

(b)

Figure 4: Effects of total aqueous extract of Justicia secunda (AJse) on hypertension Induced by sympathetic nerve stimulation of rabbit a- Recording result

A - Effects of sympathetic nerve stimulation

$($ Intensity $=6 \mathrm{mV}$, duration $=0.6 \mathrm{~ms}$, frequency $=25 \mathrm{~Hz})$

B to D - Effects of sympathetic nerve stimulation and injection of AJse at 10 (B), 20 (C) and 30 (D) mg/kg body weight (BW)

b - Reduction of hypertension induced by stimulation of sympathetic nerves by $\mathrm{A} J \mathbf{s e}$

$(\mathbf{n}=4, * \mathrm{P}<0.05, * * \mathrm{P}<0.01, * * * \mathrm{P}<0.001)$

AJse significantly reduced and even canceled hypertension induced by stimulation of the sympathetic nerve of the rabbit. 